\title{
Possible relationship between changes in islet neogenesis and islet neogenesis-associated protein-positive cell mass induced by sucrose administration to normal hamsters
}

\author{
H Del Zotto, L Massa, R Rafaeloff ${ }^{1}$, G L Pittenger ${ }^{1}$, A Vinik ${ }^{1}$, \\ G Gold ${ }^{2}$, A Reifel-Miller ${ }^{2}$ and J J Gagliardino \\ CENEXA - Center of Experimental and Applied Endocrinology (UNLP-CONICET, WHO Collaborating Center), University of La Plata School of Medicine, \\ La Plata, Argentina \\ ${ }^{1}$ Department of Internal Medicine, Pathology/Anatomy/Neurobiology, The Leonard Strelitz Diabetes Institute, Eastern Virginia Medical School, Norfolk, Virginia, \\ USA \\ ${ }^{2}$ Endocrine Research Division, Lilly Research Laboratories, Eli Lilly \& Co., Indianapolis, Indiana, USA \\ (Requests for offprints should be addressed to J J Gagliardino, CENEXA (UNLP-CONICET), Facultad de Ciencias Médicas, UNLP, Calles 60 y 1201900 \\ La Plata, Argentina; Email: gagliardino@infovia.com.ar)
}

\begin{abstract}
The possible relationship between changes in islet cell mass and in islet neogenesis-associated protein (INGAP)cell mass induced by sucrose administration to normal hamsters was investigated. Normal hamsters were given sucrose (10\% in drinking water) for 5 (S8) or 21 (S24) weeks and compared with control (C) fed hamsters. Serum glucose and insulin levels were measured and quantitative immunocytochemistry of the endocrine pancreas was performed. Serum glucose levels were comparable among the groups, while insulin levels were higher in $\mathrm{S}$ hamsters. There was a significant increase in $\beta$-cell mass $(P<0 \cdot 02)$ and in $\beta$-cell 5-bromo- $2^{\prime}$-deoxyuridine index $(P<0 \cdot 01)$, and a significant decrease in islet volume $(P<0 \cdot 01)$ only in S8 vs C8 hamsters. Cytokeratin (CK)-labelled cells were detected only in S8 hamsters. INGAP-positive cell mass was significantly larger only in S8 vs C8 hamsters. Endocrine INGAP-positive cells were located at the islet periphery $(\sim 96 \%)$, spread within the exocrine pancreas
\end{abstract}

$(\sim 3 \%)$, and in ductal cells $(<1 \%)$ in all groups. INGAP positivity and glucagon co-localization varied according to topographic location and type of treatment. In C8 hamsters, $49 \cdot 1 \pm 6 \cdot 9 \%$ cells were INGAP- and glucagon-positive in the islets, while this percentage decreased by almost half in endocrine extra-insular and ductal cells. In S8 animals, co-expression increased in endocrine extra-insular cells to $36 \cdot 3 \pm 9 \cdot 5 \%$, with similar figures in the islets, decreasing to $19 \cdot 7 \pm 6 \cdot 9 \%$ in ductal cells. INGAP-positive cells located at the islet periphery also co-expressed CK. In conclusion, a significant increase of INGAP-positive cell mass was only observed at 8 weeks when neogenesis was present, suggesting that this peptide might participate in the control of islet neogenesis. Thus, INGAP could be a potentially useful tool to treat conditions in which there is a decrease in $\beta$-cell mass.

Journal of Endocrinology (2000) 165, 725-733

\section{Introduction}

$\beta$-cell mass is the result of a final rate between opposed mechanisms such as growth and destruction. New $\beta$ cells can be formed by either mitotic division of pre-existing differentiated $\beta$ cells (replication), or differentiation from a developmental precursor or stem cell (neogenesis) (Bonner-Weir 1994, Bouwens \& Klöppel 1996, Leahy 1996).

A wide variety of processes, such as partial pancreatectomy (Cardezza \& Rodríguez 1949, Lee et al. 1989), infusion of glucose solutions (Bonner-Weir et al. 1989), dietary manipulation (Lombardo et al. 1983, Luo et al. 1998), normal pregnancy (Parsons et al. 1992), pancreatic duct ligation (Wang et al. 1995), wrapping of the pancreas head in cellophane (Rosenberg et al. 1983), and sulfonylurea administration (Loubatieres 1964), stimulate $\beta$-cell growth (Swenne 1982, Bonner-Weir et al. 1989, BonnerWeir 1994). Understanding the precise mechanism underlying these changes - particularly those obtained by modifying food intake - becomes of great interest, especially within the context of prevention (Pan et al. 1997) and treatment (Salmerón et al. 1997) of type 2 diabetes.

Several genes, hormones and growth factors are involved in the control of this growth process (Nielsen \& Serup 1998). One of these factors, islet neogenesisassociated protein (INGAP) has been identified as part of 
a protein complex called ilotropin, isolated from pancreata of normal hamsters previously wrapped in cellophane (CW) (Pittenger et al. 1991). CW of the adult hamster pancreas led to the induction of new islet formations from ducts within 2 weeks with recapitulation of normal ontogeny (Bonner-Weir et al. 1993, Bonner-Weir \& Smith 1994, Rosenberg et al. 1995, Leahy 1996) in the absence of an inflammatory response (Vinik et al. 1996). Thus, the appearance of INGAP is not the consequence of a previous acute pancreatitis, as is the case with the PAP (pancreatitis associated protein) and Reg/PSP families of genes (Gross et al. 1985, Giorgi et al. 1989, Terazono et al . 1990, Orelle et al. 1992).

It has recently been shown that INGAP is the product of a gene expressed in acinar cells but not in islets of regenerating hamster pancreata (Rafaeloff et al. 1997). Administration of ilotropin causes recapitulation of normal islet ontogeny and reverses streptozotocin (STZ)-induced diabetes mortality by 50\% (Swenne 1982, Rosenberg et al. 1988, Rafaeloff et al. 1997) through a paracrine or autocrine mechanism, rather than a hormonal one (Rosenberg et al. 1983, 1996). These data suggest that INGAP is capable of initiating duct cell proliferation, a prerequisite for islet neogenesis.

We have previously shown that sucrose administration to normal rats (Lombardo et al. 1996) and hamsters (Del Zotto et al. 1998, 1999) induces pancreas growth and islet neogenesis. However, it is not clear which factors are involved in the control of this process. Thus, in an attempt to gain new insight into this problem, we have studied the changes in glucose-induced islet growth and INGAP-cell mass by sustained administration of sucrose for a period of either 5 or 21 weeks to normal hamsters.

\section{Materials and Methods}

Twenty-four male Syrian hamsters weighing $30 \pm 2 \mathrm{~g}$ (23 days of age) were maintained in a temperaturecontrolled room $\left(23^{\circ} \mathrm{C}\right)$ with a fixed $12-\mathrm{h}$ light:darkness cycle (0600-1800 h). They were randomly divided into four groups: the two experimental groups had free access to a standard commercial diet plus $10 \%$ sucrose in the drinking water for 5 or 21 weeks (S8 and S24 respectively), whereas the two control groups received the same diet and tap water for the same periods (C8 and C24 respectively). Water intake was measured daily in all groups, while the body weight of each animal was recorded once a week throughout the experimental period.

\section{Blood parameters}

We measured glucose (glucose-oxidase method; Boehringer-Mannheim, Mannheim, Germany) and insulin (radioimmunoassay (Herbert et al. 1965)) levels in serum from each animal at the time of killing (around 0900 h).

\section{Morphological studies}

After dissecting fat tissue away from the intact excised pancreas, we recorded the total wet weight. Samples of the pancreatic tail were fixed in Bouin's fluid and embedded in paraffin. Serial sections thinner than $5 \mu \mathrm{m}$ were obtained from different levels of the block. After mounting each section from a given series on different slides, we stained adjacent sections for the immunocytochemical identification of $\beta$ and non- $\beta$ cells, cytokeratin- and 5-bromo-2'-deoxyuridine (BrdU)-labelled cells as well as INGAP-positive cells.

\section{Identification of islet $\beta$ and non- $\beta$ cells}

The following procedure was performed. Bouin-fixed, deparaffinized sections were treated with normal porcine serum to prevent non-specific staining and endogenous peroxidase was blocked with methanol/hydrogen peroxide; thereafter, the sections were incubated with appropriate dilutions of our own guinea-pig anti-insulin serum $(1: 20000)$, plus a mixture of three other rabbit sera: antiglucagon (1:400), antipancreatic polypeptide (1:10 000) (both from Novo Nordisk A/G, Denmark), and antisomatostatin (1:6000) (Dako, Glostrup, Denmark).

\section{Antigen retrieval (cytokeratin (CK) immunostaining)}

Deparaffinized sections were pretreated with $250 \mathrm{ml}$ antigen-retrieval solution (Vector Laboratories, Burlingame, CA, USA) for $10 \mathrm{~min}$ in a microwave oven $(500 \mathrm{~W})$. To reveal the presence of CK-positive cells, we used a panspecific cocktail of antibodies (1:40) against human CKs (clone AE1-AE3; Dako).

\section{INGAP-reacting cells}

Cells were identified using a specific rabbit antibody (IgG1246, 1:600) against a synthetic pentadecapeptide corresponding to amino acids 20-39 of the deduced INGAP protein sequence. The antibody was provided by Eli Lilly and Company, Indianapolis, IN, USA.

\section{Islet cell replication rate}

Islet cell replication rate was estimated in pancreatic sections obtained from animals previously injected with 25 mg/100 g BrdU (Sigma Co., St Louis, MO, USA) i.p., $1 \mathrm{~h}$ before killing (Gratzner 1982). Sections were first incubated with BrdU-specific antibodies (1:100) (Cell Proliferation Kit-RPN 20; Amersham International plc, 
Amersham, Bucks, UK), and then the fraction of $\beta$, non- $\beta$, ductal and acinar cells was quantified among the labelled nuclei as described below. The replication rate relation between the total number of cells counted (no less than 3000) and BrdU-labelled cells - was expressed as the percentage of BrdU-labelled cells from the total of such cells.

In all these cases, unless specified in the figure legends, we used the streptavidin-biotin complex method (ABC; Dako), and carbazole as chromophore. Additionally, we verified serologic specificity by preincubating a given antiserum with an excess of either the corresponding hormone or $\mathrm{BrdU}$ for $24 \mathrm{~h}$ at $4{ }^{\circ} \mathrm{C}$, or by omitting the first peptide specific antibody in the immunostaining procedure.

\section{Double immunolabelling studies}

We followed two different procedures. (1) We performed double staining of the following pairs: $\beta$ (insulin antibody) and non- $\beta$ cells (pool of glucagon+somatostatin+ pancreatic polypeptide (PP) antibodies); $\beta$ (insulin antibody) and BrdU (BrdU antibody); non- $\beta$ (antibodies pool) and BrdU (BrdU antibody). We used the streptavidinbiotin complex method, with peroxidase and alkaline phosphatase together with carbazole and fast-blue, respectively, as chromogens. Incubations with primary antibodies were overnight whereas those with the secondary biotinylated antibodies were for $30 \mathrm{~min}$. (2) For serial double-immunofluorescence labelling, sections pretreated with non-immune sera from both rabbit and mouse diluted in Tris-buffered saline ( $\mathrm{pH} 7 \cdot 4$ ) were incubated in a moist chamber at room temperature for $1 \mathrm{~h}$ with two of the hormone-specific antibodies in combination, one derived from mouse and the other from rabbit. The antibody pairs employed were: glucagon $(1: 50)+$ INGAP $(1: 300)$ (on the same section where insulin+BrdU had been previously tested); INGAP (1:300)+somatostatin (1:12.5); and INGAP (1:300)+PP (1:50). After washing with phosphate-buffered saline (PBS), fluorescence labelling of each of the pairs of primary antibodies was accomplished through a second incubation at room temperature for $45 \mathrm{~min}$ in the dark with the two IgG-specific florophore fluorescein-conjugated affinity-purified goat antibodies against rabbit $\operatorname{IgG}$ (heavy plus light chains; Jackson Immuno Research Laboratories, Inc., Baltimore, MD, USA), and rhodamine-conjugated affinity-purified goat antibody against mouse IgG (heavy plus light chains; Texas Red; Molecular Probes, Inc., Westgrove, PA, USA). After another washing with PBS, the sections were mounted in Tris-glycerol $(\mathrm{pH} 8 \cdot 4)$ for analysis by fluorescence microscopy.

\section{Morphometric analysis}

We performed the morphometric analysis by videomicroscopy in combination with OPTIMAS (Bioscan
Incorporated, Edmons, WA, USA) software in order to estimate the following parameters: total pancreas area excluding connective tissue (TP); the areas of endocrine $(\mathrm{En})$ and exocrine $(\mathrm{Ex})$ pancreas and of $\beta(\beta \mathrm{A})$ and non- $\beta$ $(\mathrm{n} \beta \mathrm{A})$ cells; and islet volume (according to Hellman 1959). We also calculated volume density of endocrine pancreas $(\mathrm{En} / \mathrm{TP})$; and volume density of $\beta$ ( $\beta \mathrm{A} / \mathrm{TP})$ and non- $\beta$ (n $\beta$ A/TP) cells. To calculate the absolute $\beta$ and non- $\beta$ cell mass, the respective volume density was multiplied by the total weight of the pancreas (Bonner-Weir et al. 1989). A similar procedure was used to measure INGAP-positive cell mass and to define its distribution within pancreatic cells.

\section{Fluorescence optics}

A Zeiss Axiolab epifluorescence microscope equipped with an HBO 50 mercury lamp was used. For visualization of fluorescein labelling, we employed two different filters to detect rhodamine and fluorescein fluorescence.

For the quantitative evaluation of immunofluorescence, positively labelled endocrine cells were counted under a $\times 40$ objective lens in sections made at different levels of the blocks. In each double-stained microscopic field, we counted, in succession, the cells that reacted positively for each one of the pairs of hormones tested, using first the appropriate set of filters for one of the fluorophores and then changing those filters to detect the other fluorescent probe. In doing so, we systematized our approach in such a way as to avoid scoring the same cell twice and thus were able to assess the total number of cells containing either or both of the hormones within each combination.

\section{Statistical analysis}

Results are expressed as the means \pm S.E.M. The statistical significance was determined by Student's $t$-test. Differences were considered significant when $P<0 \cdot 05$.

\section{Results}

Body weight and daily water intake

No significant differences were recorded in the body weights of control and sucrose-fed hamsters either at $8(\mathrm{C} 8,68 \cdot 3 \pm 7 \cdot 2$ vs S8, $66 \cdot 1 \pm 8.6 \mathrm{~g})$ or $24(\mathrm{C} 24$, $103 \cdot 53 \pm 5$ vs S24, $116 \cdot 28 \pm 5 \mathrm{~g}$ ) weeks. The S8 group drank a significantly larger volume of water than the C8 group ( $48 \cdot 2 \pm 2 \cdot 3$ vs $29 \cdot 3 \pm 4 \mathrm{ml} ; P<0 \cdot 005)$. Similar differences were recorded in S24 and C24 animals (74.54 \pm 1.3 vs $24.78 \pm 0.98 \mathrm{ml} ; P<0.001)$.

\section{Quantitative and qualitative food ingestion}

The total weight and the caloric content of the daily food consumed per animal were equivalent between the 
$\underline{8 \text { weeks }}$

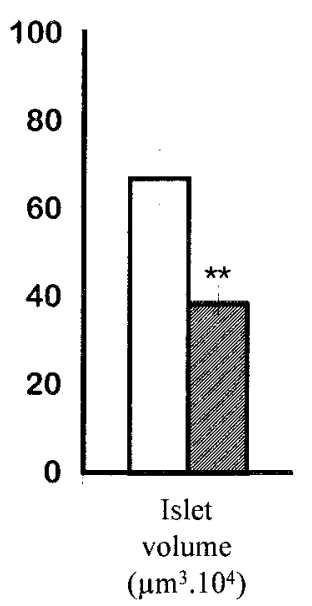

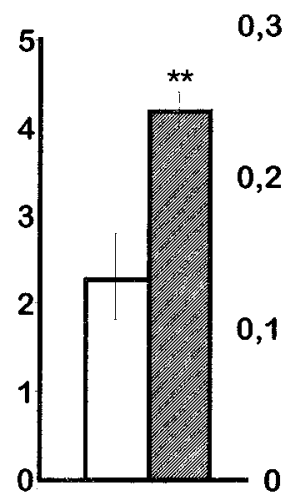

$\beta$-cell mass (mg)

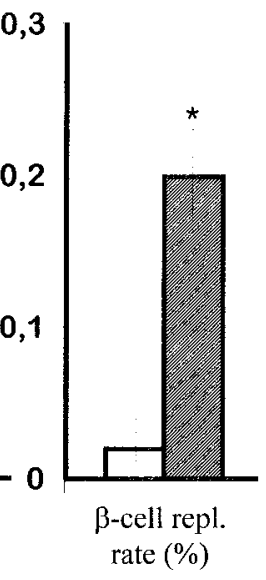

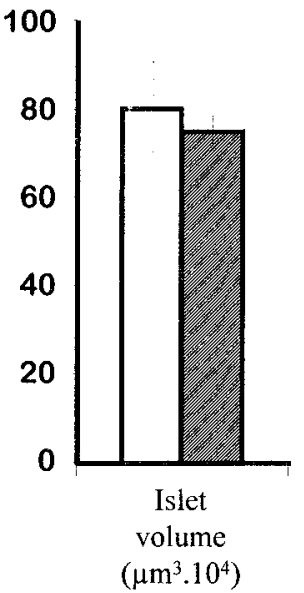
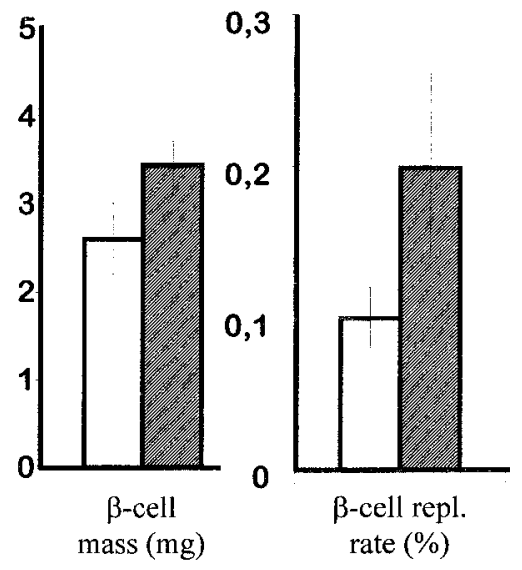

Figure 1 Morphometric study of islet cell parameters in pancreata from control (open bars) and sucrose-fed (shaded bars) hamsters. Each bar represents the mean value \pm S.E.M. of pancreata (three different levels of the block) from three animals in each age group of the paraffin block. ${ }^{*} P<0 \cdot 01 ;{ }^{* *} P<0 \cdot 007$.

sucrose-fed and the control groups (11 vs 13 g respectively and 31 vs $33 \mathrm{Cal}$ ). As shown previously (Del Zotto et al. 1999), and due to the presence of sucrose in the drinking water, the experimental animals received a qualitatively different daily intake of nutrients as compared with controls (carbohydrates:proteins:lipids, 61:30:9 vs 45:43:12 respectively).

\section{Serum-glucose and insulin levels}

The glucose levels measured in all the animals throughout this study were within the concentration range of $128 \pm 7 \mathrm{mg} / \mathrm{dl}$ found in our 20-week-old hamster colony $(n=37)$ at the time of killing. In contrast, sucrosefed hamsters had higher insulin levels: in S8 hamsters the increase was almost fourfold $(2.29 \pm 0.095$ vs $0.62 \pm 0.029 \mathrm{ng} / \mathrm{ml} ; P<0.001)$, but the difference was smaller in S24 hamsters $(2 \cdot 15 \pm 0.054$ vs $1.38 \pm 0.067 \mathrm{ng} /$ $\mathrm{ml} ; P<0.02)$. Due to the uneven behaviour of the blood glucose and insulin levels, great differences were recorded in the sucrose-fed groups relative to the corresponding control values in the insulin-glucose molar ratio (S8 vs C8, $5.3 \times 10^{-9}$ vs $1.8 \times 10^{-9} ;$ S24 vs C24, $5 \times 10^{-9}$ vs $\left.3.5 \times 10^{-9}\right)$.

\section{Morphological studies}

In all four groups, the pancreatic islets were composed of specifically stained endocrine cells, with $\beta$ cells occupying the central zone and non- $\beta$ cells located at the islet periphery. The islet shape ranged from round to ellipsoid, but the size was variable within a given histological section. A small number of ductal epithelial cells were positive for the insulin-specific antibody as well as for the pooled mixture of antisera against non- $\beta$ cell types.

\section{Morphometric studies}

There were no significant differences in C24 and S24 animals regarding the morphometric parameters, while the C8 and S8 hamsters differed significantly with respect to every parameter studied. The $\beta$-cell mass was significantly greater in $\mathrm{S} 8$ vs $\mathrm{C} 8(4.2 \pm 0.2$ vs $2.3 \pm 0.5 \mathrm{mg} ; P<0 \cdot 01)$, with similar values recorded in S24 and C24 animals $(3 \cdot 4 \pm 0.3$ vs $2 \cdot 6 \pm 0.4 \mathrm{mg}$ ). As previously reported (Del Zotto et al. 1999), significantly greater values were also recorded in $\mathrm{S} 8$ vs $\mathrm{C} 8$ in the number of islets per unit area $\left(2 \cdot 4 \pm 0 \cdot 1\right.$ vs $\left.1 \cdot 2 \pm 0 \cdot 1 \mathrm{~mm}^{2} ; P<0 \cdot 0004\right)$, and in $\beta$-cell size $\left(97 \pm 1 \cdot 6\right.$ vs $\left.88 \pm 3 \cdot 1 \mu \mathrm{m}^{2} ; P<0 \cdot 007\right)$. However, the islet volume in the S8 group was reduced to almost half that measured in C8 hamsters $(38.9 \pm 3.4$ vs $\left.66 \cdot 8 \pm 6 \cdot 1 \mu^{3}, P<0 \cdot 01\right)$. Similarly, the number of $\beta$ cells/islet was also significantly smaller in S8 than in C8 animals (S8 vs $\mathrm{C} 8,54 \pm 2$ vs $87 \cdot 8 \pm 5 \cdot 6 ; P<0 \cdot 002$ ).

The $\beta$-cell replication rate (BrdU incorporation) in S8 hamsters was tenfold that of C8 animals $(P<0 \cdot 007)$, but no significant differences were observed between S24 and C24 animals (Fig. 1). No significant differences were found in the replication rate of non- $\beta$ cells within the islets between the S8 and the C8 groups $(0 \cdot 29 \pm 0 \cdot 11$ vs $0 \cdot 26 \pm 0 \cdot 14 \% ; \quad P=$ not significant $(\mathrm{NS}))$. The BrdUincorporation rate within the exocrine pancreas (ductal, acinar, and centroacinar cells) was comparable between 


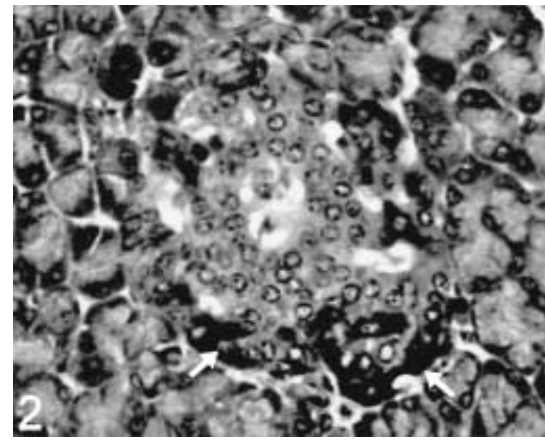

Figure 2 Presence of CKs. The immunocytochemical staining for the AE1-AE3 pool (diluted 1:40) was performed on samples from an 8-week-old sucrose-treated hamster as described in Materials and Methods. The picture is representative of the samples studied. Cells surrounding the islet (arrow) are positive for CK crossreactivity. Magnification $\times 40$.

the $\mathrm{S}$ and the $\mathrm{C}$ groups (C8 vs $\mathrm{S} 8,3 \cdot 3 \pm 0 \cdot 2$ vs $3 \cdot 6 \pm 0 \cdot 3$, and $\mathrm{C} 24$ vs S24, $2 \cdot 6 \pm 0 \cdot 2$ vs $3 \cdot 1 \pm 0 \cdot 4 \%)$.

As reported previously (Del Zotto et al. 1999), comparable values were recorded in non- $\beta$ cell volume density, size, and mass in the control and in the sucrose-fed groups at any age (data not shown).

\section{Presence of CKs in endocrine cells}

Positive CK-stained cells, located at the islet periphery (in the $\alpha$-cell locale) and in the ductal cells, were only found in S8 animals (Fig. 2), while no CK-positive cells were found in the islet periphery and in ductal cells in C8, C24 or S24 hamsters.

\section{INGAP-positive cells}

INGAP-positive cells were seen at the islet periphery (Fig. $3)$, within the extra-insular endocrine cells and in the ductus (Fig. 4). The mass of INGAP-positive cells was significantly larger in S8 than in C8 hamsters, while this difference disappeared in the mass of INGAP-positive cells in S24 animals (Table 1).
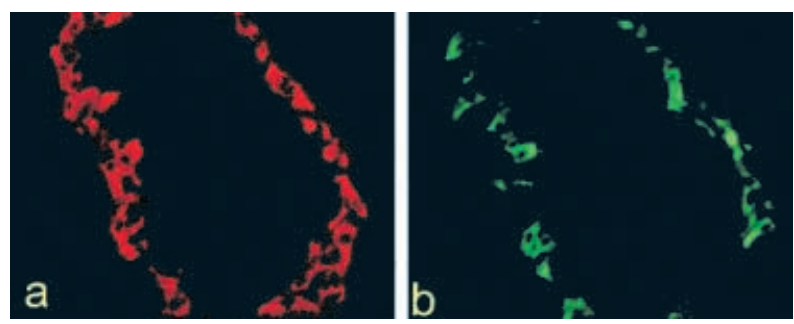

Figure 3 Immunofluorescence image of a pancreas section showing islet cells from S8 hamsters labelled with the glucagon (a) and INGAP (b) antibodies. In both cases, the positive-cells are located at the islet periphery.
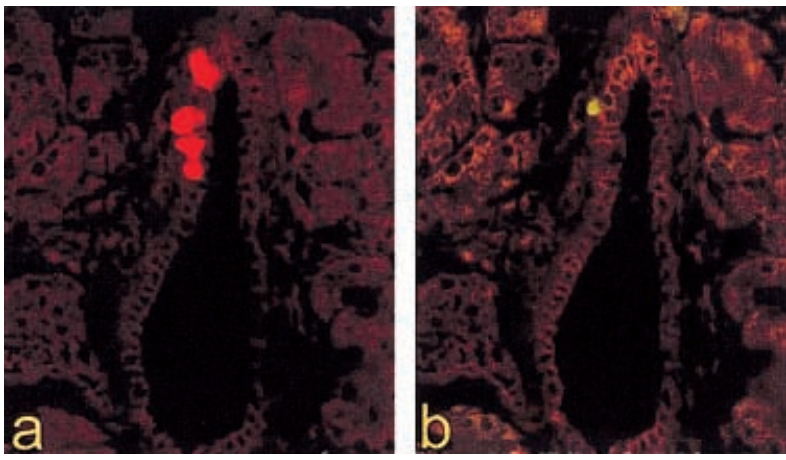

Figure 4 Immunofluorescence image of a pancreas section showing ductal cells from S8 hamsters labelled with the glucagon (a) and INGAP (b) antibodies.

Most INGAP-positive cells in all groups were located at the islet periphery (control vs sucrose, $96 \cdot 1 \pm 0 \cdot 7$ vs $96 \cdot 8 \pm 3 \cdot 8$, and $97 \cdot 3 \pm 0 \cdot 8$ vs $97 \cdot 7 \pm 0 \cdot 9$ at 8 and 24 weeks respectively), with a minor proportion spread within the extra-insular endocrine tissue $(3 \cdot 1 \pm 0 \cdot 6$ vs $2 \cdot 6 \pm 0.9$ and $2 \cdot 0 \pm 0.8$ vs $1.8 \pm 0.5)$ and in ductal cells $(0 \cdot 8 \pm 0 \cdot 2$ vs $0 \cdot 6 \pm 0 \cdot 2$ and $0 \cdot 7 \pm 0 \cdot 3$ vs $0 \cdot 5 \pm 0 \cdot 1)$. No significant differences were recorded between the two experimental groups at any of the topographic distributions of INGAP-positive cells.

A certain proportion of INGAP-positive cells simultaneously reacted with the glucagon antibody, but not with the insulin, somatostatin or PP antibodies (Fig. 5). The frequency of glucagon co-expression in these cells varied according to their location and to the type of treatment received. In C8 hamsters, $49 \cdot 1 \pm 6.9 \%$ of the INGAP-positive cells were glucagon-positive in the islets, while this percentage value markedly decreased to almost half in INGAP-positive cells located at extra-insular or ductal level (Table 2). On the other hand, in the S8 animals the percentage of INGAP-positive cells that co-expressed glucagon increased in extra-insular endocrine cells to $36 \cdot 3 \pm 9 \cdot 5 \%$ - with similar figures in the
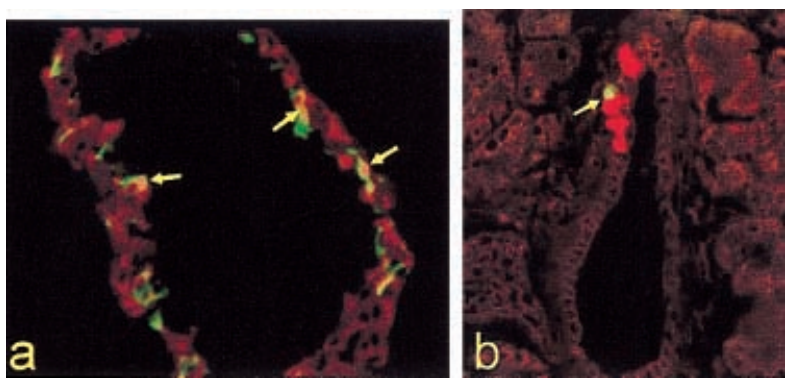

Figure 5 Double immunofluorescence staining with the glucagon (red) and INGAP (green) antibodies shows INGAP and glucagon co-expression in peripheral pancreatic islet (a; arrows) and ductal (b; arrows) cells (same pancreas sections as in Fig. 3). 
Table 1 INGAP-positive cell mass in 8- and 24-week-old control and sucrose-fed hamsters. Each value represents the mean \pm S.E.M. of three animals in each age group

\begin{tabular}{|c|c|c|c|}
\hline & $\begin{array}{l}\text { Islet-cell mass } \\
(\mathrm{mg})\end{array}$ & $\begin{array}{l}\text { Extra-insular-cell mass } \\
(\mathrm{mg})\end{array}$ & $\begin{array}{l}\text { Ductal-cell mass } \\
(\mathrm{mg})\end{array}$ \\
\hline \multicolumn{4}{|l|}{ Group } \\
\hline 8-week-old control & $0.33 \pm 0.003^{*}$ & $0 \cdot 013 \pm 0 \cdot 003$ & $0 \cdot 002 \pm 0 \cdot 0005$ \\
\hline 8-week-old sucrose & $1 \cdot 70 \pm 0 \cdot 23 \neq$ & $0.026 \pm 0.003 \dagger$ & $0 \cdot 008 \pm 0 \cdot 001 \dagger$ \\
\hline 24-week-old control & $0.62 \pm 0.08$ & $0.012 \pm 0.003$ & $0.007 \pm 0.002$ \\
\hline 24-week-old sucrose & $0.62 \pm 0.02$ & $0.020 \pm 0.004$ & $0.005 \pm 0.001$ \\
\hline
\end{tabular}

${ }^{*} P<0 \cdot 01 ; \dagger P<0 \cdot 05 ; \ddagger P<0 \cdot 02$.

Table 2 Percentage of INGAP-positive cells co-expressing glucagon, with indicators of active neogenesis in 8-week-old sucrose-fed hamsters. Each value represents the mean \pm S.E.M.

\begin{tabular}{|c|c|c|c|}
\hline \multirow[b]{2}{*}{ Group } & Islet (\%) & Ducts (\%) & $\begin{array}{l}\text { Extra-insular cells } \\
(\%)\end{array}$ \\
\hline & & & \\
\hline Controls & $49 \cdot 1 \pm 6 \cdot 9^{a}$ & $25 \cdot 8 \pm 8 \cdot 0^{\mathrm{b}}$ & $23 \cdot 1 \pm 9 \cdot 9^{c}$ \\
\hline Sucrose & $39 \cdot 4 \pm 4 \cdot 8^{a}$ & $19 \cdot 7 \pm 6 \cdot 9^{b}$ & $36 \cdot 3 \pm 9 \cdot 5^{c}$ \\
\hline
\end{tabular}

Cells counted were from pancreata of three animals from each group and three different levels each of the paraffin blocks. Despite the fact that the values recorded in each sector in the two experimental groups were different, such differences were not statistically significant. Conversely, significant differences were obtained within each group in the percentage of INGAP-positive cells according to their topographical distribution. Control: a vs $\mathrm{b}$ and a vs $\mathrm{c}, P<0 \cdot 05$; $\mathrm{b}$ vs $\mathrm{c}$, NS; sucrose: $\mathrm{a}$ vs $\mathrm{b}$ and a vs $\mathrm{c}$, NS; $\mathrm{b}$ vs $\mathrm{c}$, $P<0.05$. The number of positive cells counted was as follows: control pancreas. Islet cells: INGAP, 1037; glucagon, 2107; INGAP and glucagon co-expression, 510. Ductal cells: INGAP, 51; glucagon, 73; INGAP and glucagon co-expression, 13. Extra-insular cells: INGAP, 41; glucagon, 195; INGAP and glucagon co-expression, 10. Sucrose-treated animals. Islet cells: INGAP, 945; glucagon, 2005; INGAP and glucagon co-expression, 373. Ductal cells: INGAP, 32; glucagon, 67; INGAP and glucagon co-expression, 6. Extrainsular cells: INGAP, 32; glucagon, 113; INGAP and glucagon co-expression, 12.

islets $(39 \cdot 4 \pm 4 \cdot 8 \%)$ - decreasing to $19 \cdot 7 \pm 6 \cdot 9 \%$ in duct cells.

INGAP-positive cells frequently co-expressed CKs, but none of them showed BrdU-labelled nuclei (data not shown).

\section{Discussion}

The current results confirm that after 5 weeks of sucrose feeding, the S8 hamsters showed an increase in total endocrine-pancreas mass stemming from islet neogenesis, $\beta$-cell hypertrophy and hyperplasia (Del Zotto et al. 1998, 1999). As previously shown, these changes were accompanied by a modest increment in insulin release at lower glucose concentrations (Del Zotto et al. 1998, 1999). The increased total endocrine pancreas and $\beta$-cell mass as well as the elevated $\beta$-cell mitotic rates seen in the S8 hamsters did not increase further in the S24 animals; rather, these parameters became similar to those found in controls. Moreover, no signs of islet neogenesis - predominance of small-sized islets and presence of CK-labelled islet cells - were observed in the S24 animals, thus indicating that islet neogenesis no longer occurred at this time-period (Del Zotto et al. 1998, 1999). CKs are expressed in the rat neonatal pancreas, where rapid pancreatic-islet growth occurs from the peri-islet mantle, but not within the region composed of mature endocrine cells (Bouwens et al. 1994, Wang et al. 1994). In our study, similar results were obtained in the pancreas of normal hamsters (Del Zotto et al. 1999); CKs are therefore good markers of the neogenic zone from which layers of mantle cells derived from the ductal epithelium are added to the islet mass.

We have previously shown (Massa et al. 1997), and later confirmed (Del Zotto et al. 1999), that the endocrine pancreas of the normal hamster attains adult morphological and secretory patterns long after birth. Such patterns present a different time-sequence: the number of islets and the $\beta$-cell mass reach adult characteristics at the age of 8 weeks with no further significant changes thereafter, while maximal glucose-induced insulin release is attained only at 24 weeks of age. This suggests that at each age, $\beta$ cells can cope efficiently with the metabolic demands through different adaptative mechanisms: early in life, islet growth plays a predominant role, but since islet growth would be restricted at 24 weeks, at that time the tissue can respond to a sustained insulin demand through an enhanced capacity to release insulin in response to glucose.

It is generally accepted that, during fetal and neonatal life, islets are newly formed from precursor cells that bud off from the pancreatic ductules (Swenne 1982, Hellerström 1984). Islet growth occurs at their periphery (Conklin 1962), as observed in our S8 hamsters, where cells appear simultaneously labelled with glucagon and CK antibodies, the latter being useful markers to identify epithelial cell differentiation. As also found by other authors, only non- $\beta$ cells showed immunoreactivity for CKs in the islets, suggesting that these cells are likely to harbour the protodifferentiated stem cells (Bouwens et al. 1994, Wang et al. 1994). Our results therefore suggest that sucrose feeding duplicates fetal pancreatic development: islet cells originate within a peripheral neogenetic zone, 
indicating that they not only bud off from the ducts, but their volume can further increase by adding consecutive layers of a CK-positive cell mantle derived from the ductal epithelium.

An increased INGAP-positive cell mass was only observed in S8 hamsters, coinciding with clear signs of islet neogenesis. Further, there were no changes in this parameter in S24 hamsters when signs of neogenesis were no longer detected. The INGAP-positive cells were mainly located at the islet periphery, and they never showed a positive reaction with the BrdU antibody, but frequently did with the CK and glucagon antibodies. It is therefore tempting to speculate that they just added at the islet periphery after budding off from the ducts, and that INGAP-positive cells with no glucagon co-expression might still be at a less differentiated stage.

The other INGAP-positive endocrine cells coexpressing glucagon found at extra-insular level - also depicted only in S8 animals - might correspond to peripheral sections of the small-sized islets, which are characteristic of this experimental group. On the other hand, endocrine cells spread within the acinar tissue, reacting with the INGAP antibody but not with the glucagon antibody, might be cells that express the INGAP gene and have not yet differentiated into a specific islet hormone, or present hormone levels below the sensitivity of the detection method employed (Rafaeloff et al. 1997).

Based on the significant increase in the INGAP-positive ductal-cell mass observed in the S8 hamsters, we expected to find an increased number of these cells labelled with BrdU. The absence of such a finding might be the consequence of a rather short S-phase of ductal compared with islet cells, which could handicap the chances of labelling when using the time-schedule suitable for islet cells. It might thus be important to sample tissues at earlier time-points.

We have previously reported that sustained sucrose feeding of normal rats (Lombardo et al. 1996) and hamsters (Del Zotto et al. 1998, 1999) caused morphometric changes - indicative of islet neogenesis - similar to those currently described, while Rosenberg et al. (1988) observed that CW of adult hamster pancreata produced a $2 \cdot 5$-fold increase in islet-cell mass as a consequence of islet neogenesis. There were, however, some differences between CW (Pittenger et al. 1991) and our model: while in their control hamsters there was no INGAP expression and it appeared only after CW, INGAP-positive cells were already present in our control animals and their numbers increased significantly only when clear signs of neogenesis were present, i.e. in S8 hamsters. Differences in behaviour could probably be ascribed to the different strains employed by the two groups. For example, our hamsters have lower mean glucose levels around $130 \mathrm{mg} / \mathrm{dl}$ - compared with the $200 \mathrm{mg} / \mathrm{dl}$ in the Canadian Norfolk strain. The identification of INGAP-expressing cells in normal baboon fetuses and mouse embryos (Rafaeloff et al. 1998) also supports this assumption. Further differences were found between these two models: no apparent changes in peripheral insulin levels were reported in CW animals (Rosenberg \& Vinik 1989), while our sucrose-treated hamsters exhibited elevated insulin levels together with normoglycaemia and a high insulin:glucose molar ratio, presumably reflecting a degree of insulin resistance (Del Zotto et al. 1998, 1999).

It has been shown that the combination of high serum insulin levels together with a high insulin:glucose molar ratio, as is the case in our sucrose-fed hamsters, represents a pancreatic compensatory response to insulin resistance (Reaven 1988, De Fronzo 1997). Thus, the observed changes in the $\beta$-cell mass (increased $\beta$-cell size, replication rate, and islet neogenesis) of S8 hamsters might represent a pancreatic compensatory response to cope with the increased insulin demand. Although there is a clear overlap between the changes recorded in INGAPpositive cell mass and $\beta$-cell mass, it is, however, not completely clear which role might play the former in the mechanism of islet response, particularly in its neogenetic component.

There are facts other than these currently described suggesting that INGAP is involved in the process of islet neogenesis. (1) Administration of a partially purified protein extract isolated from CW pancreata, called ilotropin, caused recapitulation of normal islet ontogeny and reversed STZ diabetes mortality by $50 \%$ (Gross et al. 1985, Pittenger et al. 1991). (2) A synthetic pentadecapeptide, corresponding to a region unique to INGAP, significantly stimulated thymidine incorporation into the hamster duct epithelium in primary culture and into a rat pancreatic duct cell line, having no effect on a hamster insulinoma tumour cell line (Rafaeloff et al. 1997). (3) INGAP is the product of a gene expressed in the regenerating hamster pancreas (Rafaeloff et al. 1997). Western blot analysis demonstrated the presence of INGAP in ilotropin but not in extracts from control pancreata. Finally, (4) ilotropin induced islet neogenesis by a paracrine or autocrine mechanism rather than by a hormonal one (Rosenberg et al. 1983, 1996). Taken together, the available evidence suggests that the INGAP gene is a pancreatic gene whose expression is either triggered (CW hamsters) or enhanced (sucrose-fed hamsters) during islet neogenesis, and that its protein product - a constituent of ilotropin (Pittenger $e t$ al. 1991) - is capable of initiating duct cell proliferation and differentiation.

In our sucrose-fed model, INGAP might be the link between the increased insulin demand and pancreatic changes, playing an important regulatory role in islet growth and neogenesis. The present results were obtained with a relatively short-term dietary manipulation, lending further support to the concept that INGAP is a key 
component in the process of islet neogenesis, and might therefore be considered a potential tool for the treatment of conditions in which $\beta$-cell mass is seriously decreased or damaged.

\section{Acknowledgements}

This study was partially supported by funds from CONICET and CICPBA of Argentina. Thanks are due to G Luna and C Bianchi for helping with the immunocytochemical procedures, A Díaz for performing the radioimmunoassay, E Gagliardino for picture design, and A Di Maggio for careful secretarial support.

\section{References}

Bonner-Weir S 1994 Regulation of pancreatic-cell mass in vivo. Recent Progress in Hormone Research 49 91-104.

Bonner-Weir S \& Smith FE 1994 Islet cell growth and the growth factors involved. Trends in Endocrinology and Metabolism 5 60-64.

Bonner-Weir S, Deery D, Leahy JL \& Weir G 1989 Compensatory growth of pancreatic B-cells in adult rats after short-term glucose infusion. Diabetes 38 49-53.

Bonner-Weir S, Baxter L, Schuppin GT \& Smith FE 1993 A second pathway for regeneration of adult exocrine and endocrine pancreas: a possible recapitulation of embryonic development. Diabetes 42 $1715-1720$.

Bouwens L \& Klöppel G 1996 Islet cell neogenesis. Virchows Archives 427 553-560.

Bouwens L, Wang RN, de Blay E, Pipeleers DG \& Klöppel G 1994 Cytokeratins as markers of ductal cell differentiation and islet neogenesis in the neonatal rat pancreas. Diabetes 43 1279-1283.

Cardezza AF \& Rodríguez RR 1949 Acción local del estradiol sobre los islotes de Langerhans. Revista Sociedad Argentina de Biología 25 $178-182$.

Conklin TL 1962 Cytogenesis of the human fetal pancreas. American Journal of Anatomy 111 181-193.

De Fronzo RA 1997 Pathogenesis of type 2 diabetes: metabolic and molecular implications for identifying diabetes genes. Diabetes Reviews 5 177-269.

Del Zotto H, Massa L, Gómez Dumm CL \& Gagliardino JJ 1998 Changes induced by sucrose administration upon the morphology and function of pancreatic islets in the normal hamster. Diabetes 47 (Suppl 1) A415.

Del Zotto H, Massa L, Gómez Dumm CLA \& Gagliardino JJ 1999 Changes induced by sucrose administration upon the morphology and function of pancreatic islets in the normal hamster. Diabetes/ Metabolism Reviews 15 106-112.

Giorgi D, Bernard JP, Rouquier S, Iovanna J, Sarles H \& Dagorn JC 1989 Secretory pancreatic stone protein messenger RNA: nucleotide sequence and expression in chronic calcifying pancreatitis. Journal of Clinical Investigation 84 100-106.

Gratzner HG 1982 Monoclonal antibody to 5-bromo and 5-iododeoxyuridine: a new reagent for detection of DNA replication. Science 218 474-475.

Gross J, Carlson RI, Brauer AW, Margolies MN, Warshaw AL \& Wands JR 1985 Isolation, characterization and distribution of an unusual pancreatic human secretory protein. Journal of Clinical Investigation 76 2115-2126.

Hellerström C 1984 The life story of the pancreatic B cell. Diabetologia 26 393-400

Hellman B 1959 The total volume of the pancreatic islet tissue at different ages on the rat. Acta Pathologica et Microbiologica Scandinavica 47 35-50.
Herbert V, Lau KS, Gottlieb CW \& Bleicher SJ 1965 Coated-charcoal immunoassay of insulin. Journal of Clinical Endocrinology and Metabolism 25 1375-1384.

Leahy JL 1996 Impaired B-cell function with chronic hyperglycemia: 'Overworked B-cell' hypothesis. Diabetes Reviews 4 298-319.

Lee HC, Bonner-Weir S, Weir GC \& Leahy JL 1989 Compensatory adaptation to partial pancreatectomy in the rat. Endocrinology 124 1571-1575.

Lombardo Y, Chicco A, Mocchiutti N, Rodi MA, Nusimovich B \& Gutman R 1983 Effect of sucrose diet on insulin secretion in vivo and in vitro and on triglyceride storage and mobilisation of the heart of rats. Hormone and Metabolic Research 15 69-76.

Lombardo YB, Drago S, Chicco A, Fainstein-Day P, Gutman R, Gagliardino JJ \& Gómez Dumm CL 1996 Long-term administration of a sucrose-rich diet to normal rats: relationship between metabolic and hormonal profiles and morphological changes in the endocrine pancreas. Metabolism 45 1527-1532.

Loubatieres A 1964 Effects of prolonged administration of hypoglycemic sulfonamide (chlorpropamide) on the subtotally pancreatectomized dog. In The Structure and Metabolism of the Pancreatic Islets, pp 437-450. Eds SE Brolin, B Hellman \& H Knutson. New York: The Macmillan Company.

Luo J, Quan J, Tsai J, Hobensack C, Sullivan C, Hector R \& Reaven G 1998 Nongenetic mouse models of non-insulin-dependent diabetes mellitus. Metabolism 47 663-668.

Massa L, Del Zotto H, Gómez Dumm CLA \& Gagliardino JJ 1997 Postnatal sequential changes in islet morphology and insulin secretion of normal hamsters. Pancreas 14 58-64.

Nielsen JH \& Serup P 1998 Molecular basis for islet development, growth, and regeneration. Current Opinions in Endocrinology and Diabetes 5 97-107.

Orelle B, Keim V, Masciotra JC, Dagorn JC \& Iovanna J 1992 Human pancreatitis-associated protein. Journal of Clinical Investigation $902284-2291$.

Pan X, Li G, Hu Y, Wang JX, Yang W, An Z, Hu Z, Lin J, Xiao J, Cao H, Liu P, Jiang X, Jiang Y, Wang JP, Zheng H, Zhang H, Bennett P \& Howard B 1997 Effects of diet and exercise in preventing NIDDM in people with impaired glucose tolerance. Diabetes Care 20 537-544.

Parsons JA, Brelje TC \& Sorenson RL 1992 Adaptation of islets of Langerhans to pregnancy: increased islet cell proliferation and insulin secretion correlates with the onset of placental lactogen secretion. Endocrinology 130 1459-1466.

Pittenger GL, Rosenberg LG \& Vinik A 1991 Partial purification and characterization of ilotropin, a pancreatic islet specific growth factor. Journal of Cell Biology 115270 (Abstract).

Rafaeloff R, Pittenger GL, Barlow SW, Qin XF, Yan B, Rosenberg L, Duguid WP \& Vinik AI 1997 Cloning and sequencing of the pancreatic islet neogenesis associated protein (INGAP) gene and its expression in islet neogenesis in hamsters. Journal of Clinical Investigation 99 2100-2109.

Rafaeloff R, Schmitt E, Edlund H, Gold G \& Vinik AI 1998 Expression of INGAP during ontogeny of the pancreas. Diabetes 47 A259.

Reaven GM 1988 Role of insulin resistance in human disease. Diabetes 37 1595-1607.

Rosenberg L \& Vinik AI 1989 Induction of endocrine cell differentiation: a new approach to management of diabetes. Journal of Laboratory and Clinical Medicine 114 75-83.

Rosenberg L, Brown RA \& Duguid WP 1983 A new model for the development of duct epithelial hyperplasia and the initiation of nesidioblastosis. Journal of Surgical Research 35 63-72.

Rosenberg L, Duguid WP, Brown RA \& Vinik A 1988 Induction of islet cell proliferation will reverse diabetes in the Syrian golden hamster. Diabetes 37 334-341.

Rosenberg L, Rafaeloff R, Clas D, Kakugawa Y, Pittenger GL, Vinik A \& Duguid W 1995 Induction of islet cell differentiation and new 
islet formation in the hamster - further support for a ductular origin. Pancreas 13 38-46.

Rosenberg L, Vinik A, Pittenger GL, Rafaeloff R \& Duguid WP 1996 Islet-cell regeneration in the diabetic hamster pancreas with restoration of normoglycemia can be induced by local growth factor(s). Diabetologia 39 256-262.

Salmerón J, Ascherio A, Rimm E, Colditz G, Spiegelman D, Jenkins D, Stampfer M, Wing A \& Willett W 1997 Dietary fiber, glycemic load, and risk of NIDDM in men. Diabetes Care $\mathbf{2 0}$ $545-550$.

Swenne I 1982 The role of glucose in the in vitro regulation of cell cycle kinetics and proliferation of fetal pancreatic B-cells. Diabetes 31 754-760.

Terazono K, Uchiyama Y, Ide M, Watanabe T, Yonekura H, Yamamoto A \& Okamoto H 1990 Expression of Reg protein in rat regenerating islets and its co-localization in the $\beta$ cell secretory granules. Diabetologia 33 250-252.

Vinik A, Pittenger G, Rafaeloff R, Rosenberg L \& Duguid W 1996 Determinants of pancreatic islet cell mass: a balance between neogenesis and senescence/apoptosis. Diabetes Reviews 4 235-263.

Wang RN, Bouwens L \& Klöppel G 1994 Beta-cell proliferation in normal and streptozotocin-treated newborn rats: site, dynamics and capacity. Diabetologia 37 1088-1096.

Wang RN, Klöppel G \& Bouwens L 1995 Duct- to islet-cell differentiation and islet growth in the pancreas of duct-ligated adult rats. Diabetologia 38 1405-1411.

Received 9 November 1999

Accepted 8 February 2000 